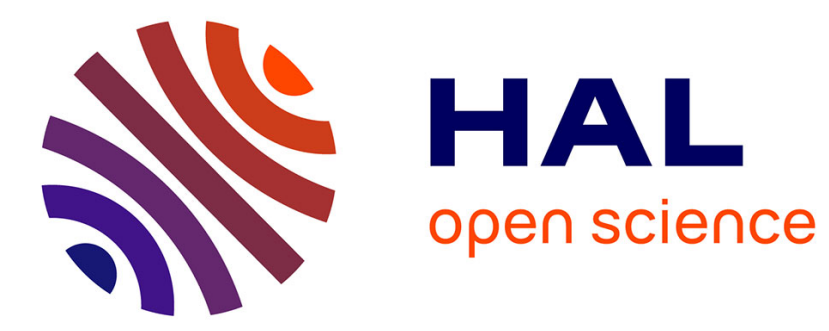

\title{
Littoral Survey Using the JERS-OPS Multispectral Sensor: Example of the Mont-Saint-Michel Bay (Normandy, France)
}

\author{
Jean-Paul Deroin, Yvette Vaguet-Marchand, Jean-Paul Auffret
}

\section{To cite this version:}

Jean-Paul Deroin, Yvette Vaguet-Marchand, Jean-Paul Auffret. Littoral Survey Using the JERS-OPS Multispectral Sensor: Example of the Mont-Saint-Michel Bay (Normandy, France). Remote Sensing of Environment, 1997, 62 (2), pp.119-131. 10.1016/S0034-4257(97)00080-1 . halshs-01821759

\section{HAL Id: halshs-01821759 \\ https://shs.hal.science/halshs-01821759}

Submitted on 6 Aug 2018

HAL is a multi-disciplinary open access archive for the deposit and dissemination of scientific research documents, whether they are published or not. The documents may come from teaching and research institutions in France or abroad, or from public or private research centers.
L'archive ouverte pluridisciplinaire HAL, est destinée au dépôt et à la diffusion de documents scientifiques de niveau recherche, publiés ou non, émanant des établissements d'enseignement et de recherche français ou étrangers, des laboratoires publics ou privés. 
Deroin, J.-P., Vaguet]-Marchand, Y.\& Auffret, J.-P. 1997. Littoral survey using the JERS-OPS multispectral sensor: Example of the mont-saint-michel bay (Normandy, France). Remote Sensing of Environment, 62 ,

\section{Littoral Survey Using the JERS-OPS Multispectral Sensor: Example of the Mont-Saint-Michel Bay (Normandy, France)}

Jean-Paul Deroin, ${ }^{*}$ Yvette Marchand,${ }^{\dagger}$ and Jean-Paul Auffret ${ }^{\dagger}$

\begin{abstract}
A JERS-1 OPS (Japanese Earth Remote Sensing Satellite, Optical Sensor) image was used to make a methodological survey of the Mont-Saint-Michel foreshore (West of France). The main objective was to test different procedures for processing multispectral data between 520 $\mathrm{nm}$ and $2400 \mathrm{~nm}$ so as to refine the information acquired from other sensors such as Spot XS and Landsat TM which have a lower spectral and spatial discrimination potential. The use of multispectral satellite data enables a rapid reconnaissance of the zone where both sedimentological and morphological evolution occur according to the tides. The OPS sensor appears able to detect carbonate responses (Channel 6), especially in suspension in the turbid plume of the estuary water. JERS-OPS distinguished clearly between clays, vegetation, and the effect of phenomena likely to perturb their response, mainly moisture characterized by Channel 5.
\end{abstract}

\section{INTRODUCTION}

The coastal sectors of epicontinental shelves such as the English Channel show exceptional tidal amplitudes, with the tidal range often exceeding $10 \mathrm{~m}$. Thus, in certain areas, the foreshores can be exposed over several hundreds of square kilometers, reaching a maximum during low spring tides. These zones are highly sensitive to the accumulation of sediments, which varies considerably in time and space.
In spite of frequent aerial photograph missions, only satellite imagery is capable of providing a regular and global monitoring of the modifications that occur in such an environment. Satellite scenes cover several thousands of square kilometers and their geometric distortions are easily corrected in optical imagery. The spatial resolution of modern optical sensors is adequate for a cartographic approach to the phenomena: $30 \mathrm{~m}$ for Landsat-Thematic Mapper, $20 \mathrm{~m}$ for Spot-XS, and $18 \mathrm{~m}$ for JERS-Optical sensor. The spectral characteristics, in particular in the mid-IR range, make it possible to obtain information, either directly or through the use of ratios, in the mineral and plant domains.

Surveys of the littoral zone by multispectral imagery allows investigation of extensive areas having a purely, or at least predominately, mineral response that is unique in a temperate zone (Marchand, 1996; L'Homer and Minoux, 1987). Moreover, the landscape units are homogeneous over large areas, which is compatible with the pixel size.

A priori the fields of interest in a survey of foreshore zones concern mainly sedimentology, that is, the nature and structure of sedimentary bodies and their morphology. For the present approach we shall restrict ourselves to the supratidal zone, which is likely to be exposed at least once a year. The pseudobathymetric aspects will not be considered in detail. Under certain observation conditions, in particular for only slightly turbid zones and using Channel 1 (blue zone) of Landsat Thematic Mapper, correct results could be obtained below water depths of a few meters (Baban, 1993; Bierwirth et al., 1993; Spitzer, 1989). However, the respective roles of turbidity and water depth are not often easy to quantify. Moreover, the turbidity is compatible with large tidal amplitudes and with the presence of estuaries or river mouths contributing a substantial quantity of sediment from the continent and with the remobilization of foreshore sediments. Thus, the best results 
Table 1. Comparison of Spectral Bands (Expressed in 1 m. of JERS-I OPS. Lindsat-TM, and Spot-XS

\begin{tabular}{|c|c|c|c|}
\hline Chammel & JERS-OPS & LANDSAT-TM & SPOT-XS \\
\hline 1 & 52()$-6()()$ & 4.5()$-.52()$ & 5()()$-\overline{5} 9()$ \\
\hline 2 & $6: 30-6990$ & $\overline{5} 2()-(f())$ & $610-68()$ \\
\hline$: 3$ & 76()$+S 6()$ & $63(1)-69()$ & $7 y()-s(y)$ \\
\hline 4 & 76()$-86()$ & $7(6()-9()()$ & $\ldots$ \\
\hline 5 & 16() $0-1710$ & 15.5()$-1750$ & $-\cdots$ \\
\hline 6 & 2() $\mid()-212()$ & 1()$, 4()()-12.5()()$ & - \\
\hline 7 & $21: 3()-2.25()$ & 2()$S()-2335()$ & - \\
\hline$s$ & 227()$-24()()$ & - & - \\
\hline
\end{tabular}

in the bathymetry domain were obtained on lagoons (e.g., Pirazzoli, 1984; Garlan, 1991).

\section{THE JERS DATA}

The Japanese Earth Resources satellite, JERS-1, was launched on 11 February 1992. It has on board both an OPtical Sensor (OPS) and a Synthetic Aperture Radar (SAR) (Nishidai, 1993). Its orbit, at an average altitude of $568 \mathrm{~km}$, is heliosynchronous and subpolar, meaning that the highest latitudes cannot be covered; the inclination is $97.7^{\circ}$. The descending node equator crossing time is around 11:00 h GMT, about $1 \mathrm{~h}$ after Landsat TM, which takes advantage of the clearer morning atmosphere, and at about the same time as Spot. These conditions reduce the shadows thrown and the perception of certain morphological phenomena. The satellite has 15 96-min orbits a day; its 44-day revisit frequency is low.

The JERS-1 OPS system has two radiometers; one a Visible-Near Infrared Radiometer (VNIR) and the other a Short Wavelength Infrared Radiometer (SWIR) operating in the mid-IR (Table 1). Each scene covers $75 \times 75 \mathrm{~km}\left(5625 \mathrm{~km}^{2}\right)$, with nominal spatial resolution of $18.3 \mathrm{~m} \times 25.4 \mathrm{~m}$. The JERS system allows the acquisition of oblique foreviews, which permit the use of stereoscopy in the near infrared (Channels 3 and 4). Stereoscopy is particularly useful for geologists in areas of poor topographical contrast (Chorowicz et al., 1991).

Preliminary tests of the OPS instrument revealed technical problems limiting its use for certain applications, in particular the reconnaissance of mineral alterations (Okada et al., 1994). The SWIR channels show response discrepancies at various radiance levels, giving blurred images. Moreover, saturation problems may appear, in particular in two spectral bands (OPS 5 and OPS 7 ), for certain acquisition modes. In general, the VNIR data are good quality whereas the SWIR data have noise and column calibration discrepancies.

JERS-1 does, however, offer some substantial advantages compared with the Spot and Landsat operational satellites. Although the OPS spectral bands range over the same spectrum as those of the Landsat Thematic Mapper, the instrument on board the JERS is the first satellite sen- sor to provide more than once spectral band in the atmospheric window at $2200 \mathrm{~mm}$. This zome of the electromagnetic spectrum is of special importance in mineral discrimination (Table 1), and three bands are centered on $2065 \mathrm{~nm}$ (OPS 6), 2190 $\mathrm{nm}$ (OPS 7), and 23:35 $\mathrm{mm}$ (OPS 8). Also, the theoretical spatial resolution is slightly better than that of Spot XS.

Specific processing methods have been tested by various authors using OPS images. Taranik et al. (1994), for instance, developed principal component analysis (PCA) methods from OPS Bands 1-5 and 7. The first principal components carry the main data, which is usual, but other work has shown that the signal/noise ratio did not necessarily evolve linearly. With JERS-I OPS, signal noise (annot be totally isolated due to weak interband correlation of the noise, which means that the PCA could not concentrate the effects of the noise on the highest order principal components (de Souza Filho) et al., 1994). Kaufimann et al. (1994) demonstrated that the carbonates could be recognized from the principal components 2 and 3 , and that they were characterized by minor variations on the principal components 4 and 5. Ferruginous minerals show a strong response in components 2 and 6 . Principal component 7 mainly concentrates noise. During the same study, Kaufmann et al. (1994) stressed the usefulness of Channel OPS 7 in distinguishing zones containing ferruginous minerals, Channels OPS 3 and OPS 1 for kaolinite and gypsum, and Channel OPS 3 for Al-OH-radical clays. Malila and Meyers (1994) tested the tasseled-cap transform. which consists in creating indices such as brightness and greeness. The result, from OPS, proves to be close to that obtained with Landsat TM.

The JERS data used for the study zone has the reference 330-219. It was acquired on 29) July 1992 at 11:16 h GMT (i.e., 13:16 h local time). The foreshore is well exposed as it was $1 \mathrm{~h} 7 \mathrm{~min}$ before a high-coefficient low tide.

The meteorological archives (Cancale station, west of Mont-Saint-Michel Bay) indicate that the last signifi(ant rainfall occurred on 20) July (some $20 \mathrm{~mm}$ rain fell in over $5 \mathrm{~h}$ ). Considering the season, the effect of the ground moisture associated with this rainfall can be ignored. Also the wind velocity was almost nil at the time of acquisition $\left(1 \mathrm{~km} \mathrm{~h}^{-1}\right)$.

\section{THE SITE TEST}

Mont-Saint-Michel Bay (Fig. 1), at the base of the Gulf of Saint-Malo dividing Normandy from Brittany, covers some $500 \mathrm{~km}^{2}$ at the heart of the Armorican Massif, in an oceanic temperate climate (Larsonneur, 1989; Lang et al., 197:3). It is characterized by an exceptional tidal amplitude: $15 \mathrm{~m}$ during spring tides. Associated with a very slight northwest-trending slope (3\%o on average), the width of the foreshore reaches $15 \mathrm{~km}$ along the long 

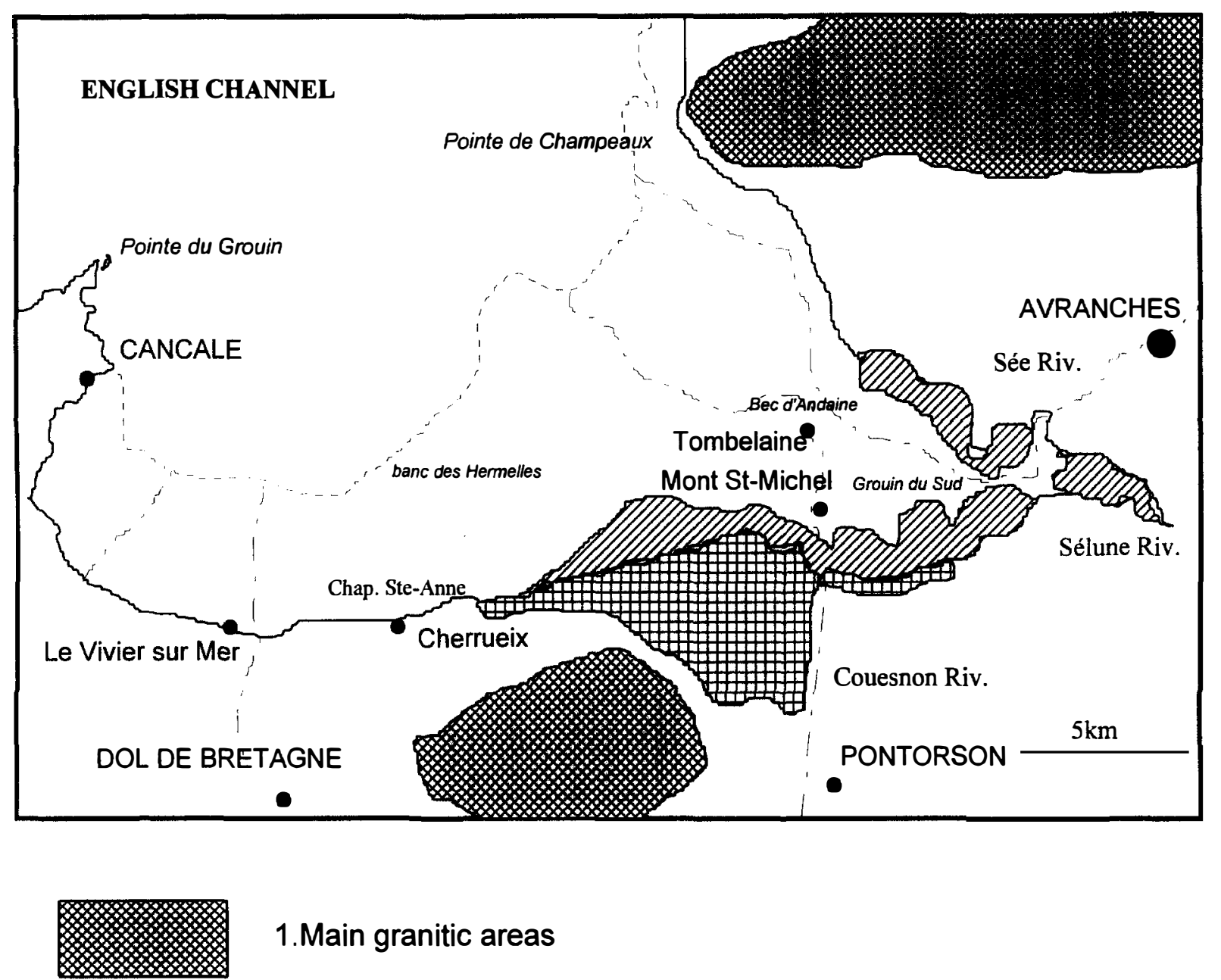

1.Main granitic areas

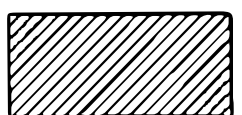

2.Main schorre areas (herbus)

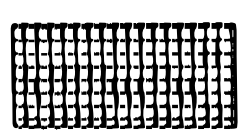

\section{Polders}

\section{Lower limit of the foreshore}

Figure 1. Location of Mont-Saint-Michel Bay.

axis of the bay which opens into the Gulf. The emerged foreshore can then be as much as $250 \mathrm{~km}^{2}$, that is, half the bay. Three rivers, the Sée, the Sélune, and the Couesnon, form a preestuarine delta in the innermost part of the bay, to the east-southeast. The polders are contained by dikes.

The land surrounding the bay is made up of recent alluvial deposits in the lower parts. Schistose Upper Proterozoic formations, overlooked by a few granodiorite massifs crop out abundantly to the east (Cotentin Peninsula) and to the west on around the Saint-Malo gneiss massif. The two leucocratic granite outcrops of Mont-SaintMichel and Tombelaine emerge through the beaches of the preestuarine delta.
The landscape is wadden type, that is, an ample sandy foreshore. The clayey-silty deposits of the upper part (or schorre) are colonized by pasturable halophytes with a predominance of Puccenellia (salt meadows) followed by the obione schorre and its equivalents in the lower part. The middle part of the foreshore consists mainly of tangue, a carbonate material with alternate silty and sandy layers related to the tidal cycle. Shelly banks, swept by the swell, overlie this unit in the western part. A reef of Polychaeta annelids (Sabellaria alveolata) known as Les Hermelles lies in the central part of the bay. This acts as an effective breakwater and is associated with a bank of shell sand: La Grande Bosse. The Bec d'Andaine, in the northeast of the bay, is the only zone 
facing the open sea and is thus subjected to the action of swell from the northwest. The result is a range of dunes isolating the salt marshes.

\section{MINERAL DISCRIMINATION POTENTIAL OF THE JERS-OPS DATA}

The sediments of a foreshore are mainly silicocalcareous type. The carbonate component is sometimes concentrated in the form of bars resulting from the accumulation of thanatocoenoses by the swell, in particular, in certain sectors of the schorre. The clay fraction forms stable deposits at the top of the profile and unstable deposits at the base.

The sedimentary bodies of Mont-Saint-Michel Bay are mainly sandy, and result from the accumulation of erosion products from the Armoricain Massif. These deposits always include a sizeable carbonate fraction, $50 \%$ on average, which can be as much as $90 \%$ in the bioclastic accumulations of the upper foreshore.

Our own measurements on samples from the foreshore showed $25-80 \%$ carbonates. Calcite is generally predominant, with 5-25\% associated aragonite plus a high proportion of magnesium calcite in the western part of the bay where it can reach $20-60 \%$ of the total carbonate component (Larsonneur, 1989). The tangue, composed of sand, silt and clay, contains $40-55 \%$ limestone. This sediment, which is carbonate-rich but clay-poor, has specific physical properties that render it semipermeable with low cohesion and flocculation factors. The result is an unusual surface condition, different from that of the silty sediments.

Various authors have noted a considerable homogeneity of the clay mineral suites within the Gulf of SaintMalo. Illite, kaolinite, and chlorite (and various interstratified minerals) each represent about one third of this clayey fraction (Larsonneur, 1989).

\section{Response of the Principal Minerals (Fig. 2)}

The values obtained by satellite correspond to radiances, that is, to relative quantities of reflected energy expressed in digital numbers. Their link with the real reflectances of the surfaces depends on the calibration of the sensor and the parameters of the luminous source, mostly the sun.

The spectral characteristics of rock and soil are due to the vibrations and electronic transitions induced by the constitutive minerals, which give a certain number of characteristic absorption bands separated by relative reflection peaks. In the visible and the beginning of the infrared bands, the nonferruginous minerals show few outstanding features.

Band 7 of Landsat thematic Mapper, centered on $2200 \mathrm{~nm}$, offers the possibility of recognizing rocks and soils containing minerals characterized by $\mathrm{CO}_{3}^{2-}, \mathrm{H}_{2} \mathrm{O}$.
$\mathrm{OH}^{-}$, and $\mathrm{SO}_{4}^{2--}$ anions and molecules. However the recognition potential is reduced by the presence of a 270 $\mathrm{nm}$ wide band which also extends into a high-reffection vegetation field. The three SWIR spectral bands of JERS-OPS, with widths of 110-130 $\mathrm{mm}$. theoretically give a resolution that is much more favorable for the identification of minerals. The (OPS spectral resolution is thus intermediate between the claimed resolutions of 10 $\mathrm{nm}$ in AVIRIS-type multispectral aerial imagery (Porter and Enmark, 1987) and the resolntion of operational optical satellite imagery.

Carbonates (Hunt and Salisbury, 1971): The basic vibration modes of carbonates are in the thermal infrared range $(5000)-12,(000 \mathrm{~nm})$. In the VNIR-SWIR range the spectra arc complex. They result in the superposition or combination of harmonics corresponding to the electronic transitions of the cations, ions and impurities, in addition to the vibrations belonging to the $\mathrm{CO}_{3}^{2-\cdots}$ radical. All the carbonates (e.g., calcite, dolomite, aragonite, siderite, magnesite) have five characteristic absorption bands between $1600 \mathrm{~nm}$ and $2500 \mathrm{~nm}$. The two farthest absorption bands within the electromagnetic spectrum, that is, around $2300 \mathrm{~nm}$ and $2500 \mathrm{~nm}$-the latter not being covered by OPS-are the most intense. The result is a strong reflection peak at about $2100 \mathrm{~nm}$ (OPS 6), and a less marked reflection peak around $2200 \mathrm{~nm}$ (OPS 7 ). It is not possible to interpret the response in (OPS $8 \mathrm{di}$ rectly in relation to the carbonates because of the conjunction of a high absorption and a relative reflection peak. Due to the ease with which the $\mathrm{Ca}^{2+}$ ions can be substituted by other metallic cations, such as $\mathrm{Fe}^{2+}$, it is theoretically possible to obtain absorption bands around $1000 \mathrm{~nm}$ (ferrous ions), which is not detectable by JERSOPS. The carbonates can thus be characterized from the SWIR, in particular through a strong response in OPS 6 , as the calcite has a reflectance globally stronger than other carbonates and clays (Lang et al., 1990); Whitney et al., 198:3). Responses in OPS 7 and OPS 8 are weaker.

Silicates (Hunt and Salisbury, 1970): In the foreshore zone, the two principal silicate families are clays and pure silica $\left(\mathrm{SiO}_{2}\right)$. The latter does not have a notable spectral behavior in the range considered. The same applies to the feldspars.

The clays are hydrated phyllosilicates, meaning that their reflection spectrum always shows water absorption bands [at $1400 \mathrm{~nm}(\mathrm{O}-\mathrm{H})$ and at $1900 \mathrm{~nm}(\mathrm{O}-\mathrm{H}, \mathrm{H}-$ $\left.\mathrm{O}-\mathrm{H}, \mathrm{H}_{2} \mathrm{O}\right]$. Their structure is governed by the superposition of falkes made up of tetrahedric and octahedric layers. The kaolinite, like the illite and the alunite $\left[\mathrm{KA}_{3}\right.$ $\left(\mathrm{SO}_{4}\right)_{2}(\mathrm{OH})_{6}$ J gives, other than the water absorption band at $1400 \mathrm{~nm}$, an absorption band centered on $2200 \mathrm{~nm}$ (OPS 7), which corresponds to the presence of the $\mathrm{Al}-\mathrm{OH}$ radical. This absorption band can cover another band at $2120 \mathrm{~nm}$ related to the radical $\mathrm{NH}_{4}$ (e.g., certain smectites). Thus the response observed in OPS 7 will be very weak. the responses of OPS 5,6 , and 8 being 
Figure 2. Relative reflection spectra for some minerals in the 400-2500 $\mathrm{nm}$ range (from a compilation of data by Hunt and Salisbury, 1970; 1971; Whitney et al., 1983; Hauff, personal communication, 1996): 1) hematite; 2) goethite; 3) ankerite; 4) quartz; 5) gypsum; 6) calcite; 7) pyrophyllite; 8) talc; 9) montmorillonite; 10) kaolinite; 11) dickite; 12) illite; 13) muscovite; 14) alunite; 15) chlorite.

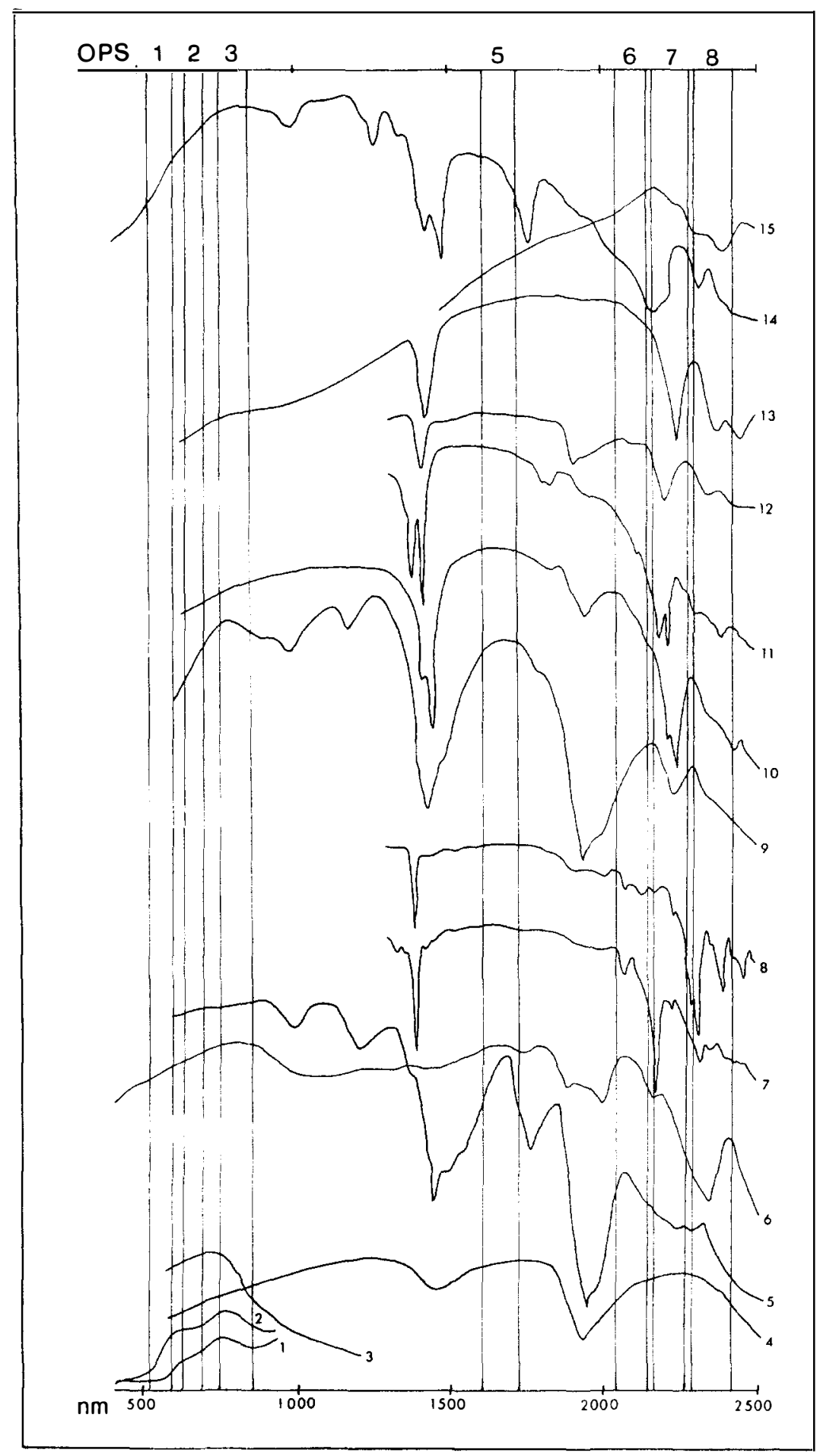

in the dolomite by $\mathrm{Fe}^{2+}$, gives a large reflection peak centered on $700 \mathrm{~nm}$, but this is not clearly identifiable on OPS 2 as the band stops at $690 \mathrm{~nm}$. The iron content of the soils can thus be approximately determined by measurements in the 630-690 nm (OPS 2) and 1150$1300 \mathrm{~nm}$ ranges (Guyot, 1989). Hematite also shows a characteristic absorption band at $850 \mathrm{~nm}$ (Kruse et al., 1990). Considering the spectral characteristics of the NIR (OPS 3) band of JERS which stops at $860 \mathrm{~nm}$, the strong. For magnesium chlorites, which involve the radical $\mathrm{Mg}-\mathrm{OH}$, the absorption peak is shifted to about $2300 \mathrm{~nm}$ (OPS 8). The illite also shows two original absorption bands at 2340 (OPS 8) and $2440 \mathrm{~nm}$ (outside the OPS spectrum).

Ferrous oxides: Between 400 and $900 \mathrm{~nm}$, the ferrous $\left(\mathrm{Fe}^{2+}\right)$ and ferric $\left(\mathrm{Fe}^{3+}\right)$ ions are the source of most of the remarkable bands observed. For instance, ankerite, which corresponds to a substitution of certain $\mathbf{M g}^{2+}$ 
hematite absorption band is less easily perceived than with (Chamnel 4 of Landsat-TM (up to 900 nim) or Cllanmel 3 of Spot-XS (to $890 \mathrm{~mm}$ ). In fact, ferrons oxides always occur in variably proportioned mixtures, which makes it impossible to attribute a specific spectral response to one mineral or another.

Gypsum: Gypsum $\left(\mathrm{CaSO}_{4}, 2 \mathrm{H}_{2} \mathrm{O}\right)$ and also the variety of calcium sulfate with hydroxyls (anhydrite) give theoretically strong responses for OPS 5 and weak responses for OPS 6 and OPS 7 . Due to its chemical composition. gypsum shows marked water absorption bands.

\section{Phenomena Perturbing the Spectral Response of Mineral Surfaces}

Water: Generally, and for the entire electromagnetic spectrum from $400 \mathrm{~nm}$ to $2500 \mathrm{~nm}$, moisture tends to lower the reflectance of natural surfaces. Therefore, the wetter the ground, the lower its reflectance. This phenomenon is due to part of the soil porosity being filled with water, which reduces the refraction index of the air-particle interfaces. Measurements made on samples of sediments from the Mont-Saint-Michel foreshore gave rates of $8-49 \%$ water.

Exposed sediments are likely to dry out rapidly, due to the combined action of sun and wind, which considerably limits the possibility of "quantifying" the water content of the ground from simple radiance data recorded by a satellite sensor.

Organic matter: The organic matter content has a strong impact on the optical properties of the ground when it exceeds $2 \%$, mainly between 600 and $850 \mathrm{~nm}$. The effect then decreases; above $1800 \mathrm{~nm}$, it is much less apparent (Guyot, 1989). Our measurements on samples taken in the bay gave maximum contents of $1.26 \%$ total organic carbon, that is, over $2 \%$ organic matter. The analysis points are, however, too few for reliable conclusions to be drawn regarding possible perturbation of the reflection.

Vegetation cover: In the littoral zone, plants cover most of the upper foreshore (schorre) and the terrestrial zone (forests, crops, etc.). Halophytes and sclerophyllic plants on the schorre and upper slikke show ordinary plant characteristics: weak reflectance peak in the green (OPS 1) and strong reflectance in the NIR (OPS 3) and SWIR (OPS 5), and relative reflectance peak at about $2200 \mathrm{~mm}$ (OPS 7 ), this being always inferior at OPS 3 (Katoh, 1994). Maximum reflectance values in the NIR of plants such as obione or glasswort have a modest amplitude compared with those of leafy and other plants with intense photosynthetic activity. By contrast the responses of the lower schorre seem superior to those of the salt meadow, both in the NIR (OPS 3) and in the SWIR (OPS 5). The development of diatoms on the foreshore should also be noted, as this can have a local impact on the response in the visible range of the electromagnetic spectrum.

\section{RESULTS}

\section{Data Preparation}

The numerical data were snpplied on a c(CT support by NASDA, within the scope of the JERS-(0:30.5 pilot project (Deroin et al., 1994). The ()PS sensor being particularly suitable for geological studies, it appeared interesting to test it on the "purely" mineral domain of the foreshore.

\section{Quality of the Data and General Information}

The OPS 2 and OPS 7 files show considerable noise with a column discrepancy. The most legible channels are OPS 1, OPS :3, (OPS 4), and OPS 5. Channels OPS 6 and OPS 8 are slightly "hazy" (Fig. 3).

In the maritime zone, the turbid plume can be clearly seen in the infrared spectrum, except in OPS 7. Distinctions appear in OPS 6 and OPS 8. By thresholding OPS 6 for different levels of digital numbers, we obtain a pseudobathymetric perception which can be interpreted in terms of a concentration gradient of suspended particles in the water. The tide level-always difficult to determine accurately due to the high content of suspended matter and the very gentle slope (Pestre and Verger, 1980)_-an be determined approximately on OPS 3 , OPS 5, OPS 1 , and OPS 7.

\section{Cartographic Contribution of Each Channel (Table 2)}

OPS $1(520-600 \mathrm{~nm})$ and OPS $2(630-690 \mathrm{~nm})$ : The information in the visible range being very well correlated $(r=0.93$ for the scene, $r=0.99$ for the foreshore zone) and OPS 2 being poor quality, the study can be limited to OPS I. In this channel, the features having the strongest response are the accumulations of sand on which specular reflection phenomena can occur. Sand is clearly visible at the Bec d'Andaine, at the Grouin du Sud, on the distal part along the grazing land and in the Grande Boss bank. These sands, most of them dry, are distinguished from those in the lower to middle intertidal part. which are wetter and mixed with mud (part tangue).

In the estuary zone, the chamnels are clear due to the absence of response from the water. On the foreshore, exposed over some $2 \mathrm{~km}$ in the vicinity of Viviersur-mer, clear distinctions can be made between the verv wet silty zones with a weak response and those sectors, slightly higher topographically, which have a stronger response. The latter can be related to the presence of sand and carbonates and, probably, a rougher surface condition (ripple marks).

OPS $3($ or OPS 4) $(760)-860 \mathrm{~nm})$ : As the scene was acquired in midsummer at the height of plant activity, this is the ideal channel for studying the vegetation as a whole, particularly in the schorre zone. It is possible to identify increasingly strong responses from certain sectors of the schorre and the upper slikke. the salt meadows, towards the polders used for crops. Maximum re- 

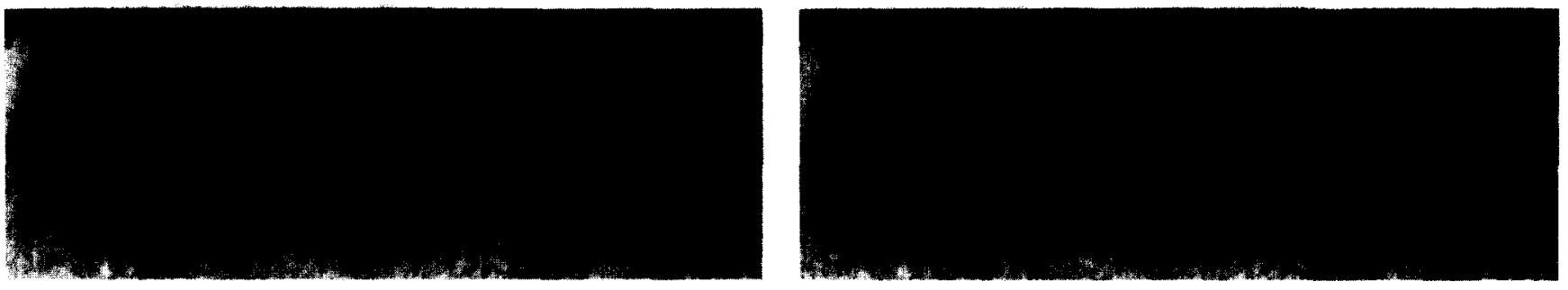

3
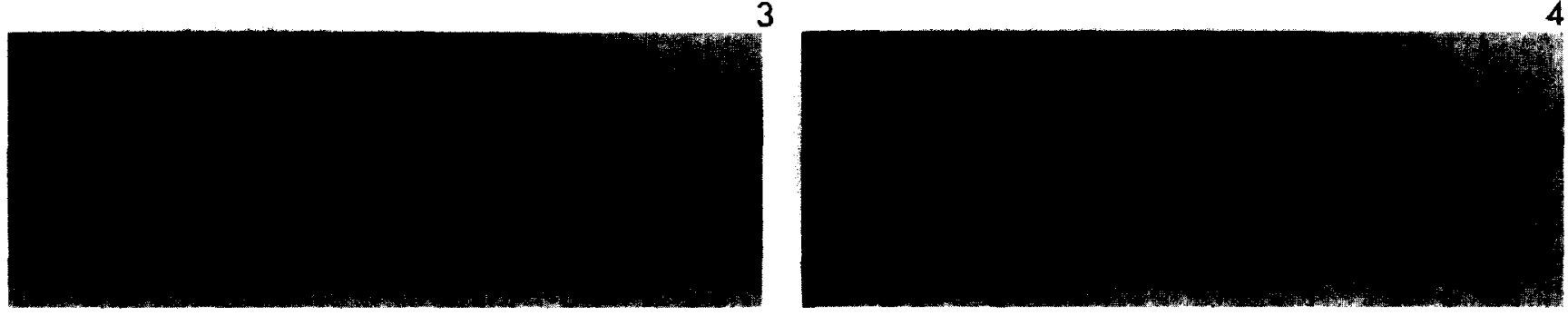

5
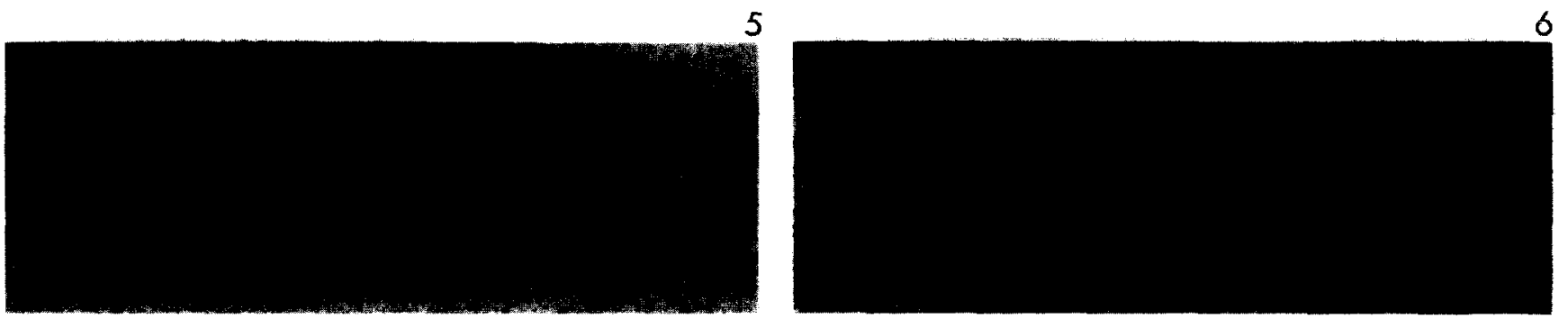

7

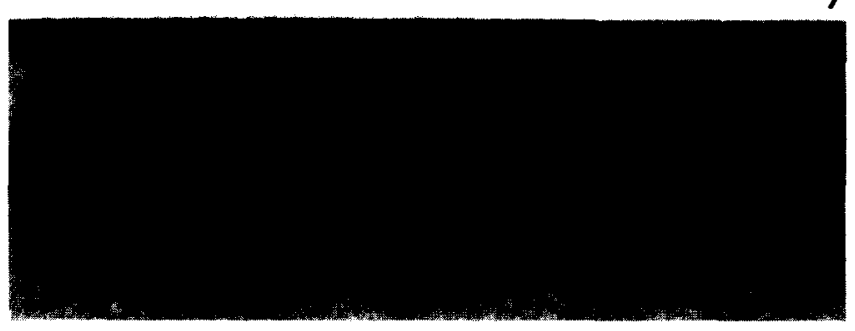

Figure 3. The 8 JERS-OPS channels in grey levels.

sponses are observed for deciduous forests (e.g., Saint Léonard).

OPS $5(1600-1710 \mathrm{~nm})$ : The mid-IR is particularly sensitive to humidity. It is strongly correlated in the NIR

Table 2. Variance/Covariance/(Correlation Matrix: Total Area

\begin{tabular}{lcccccccc} 
& OPS 1 & OPS 2 & OPS 3 & OPS 5 & OPS 6 & OPS 7 & OPS 8 \\
\hline OPS 1 & 12.3 .6 & 78.8 & 257.6 & 208.7 & 6.4 & 218.6 & 54.6 \\
OPS 2 & $\mathbf{0 . 9 3}$ & 58.1 & 139.2 & 102.6 & 8.5 & 135.2 & 40.3 \\
OPS 3 & $\mathbf{0 . 7 5}$ & $\mathbf{0 . 5 9}$ & 967.4 & 875.7 & -6.3 .5 & 568.7 & 17.3 \\
OPS 5 & $\mathbf{0 . 5 9}$ & $\mathbf{0 . 4 2}$ & $\mathbf{0 . 8 8}$ & 1016.4 & -68.6 & 494.9 & -3.8 \\
OPS 6 & $\mathbf{0 . 0 8}$ & $\mathbf{0 . 1 5}$ & $-\mathbf{0 . 2 7}$ & $-\mathbf{0 . 2 9}$ & 55.9 & -15.2 & 77.2 \\
OPS 7 & $\mathbf{0 . 8 4}$ & $\mathbf{0 . 8 4}$ & $\mathbf{0 . 8 7}$ & $\mathbf{0 . 7 4}$ & $-\mathbf{0 . 1 0}$ & 442.4 & 64.8 \\
OPS 8 & $\mathbf{0 . 4 1}$ & $\mathbf{0 . 4 5}$ & $\mathbf{0 . 0 5}$ & $-\mathbf{0 . 0 1}$ & $\mathbf{0 . 8 7}$ & $\mathbf{0 . 2 6}$ & 140.5 \\
\hline
\end{tabular}

(OPS 3). This channel is interesting for its discrimination of certain plant types. Thus, the populations of the upper slikke and the lower schorre (obione) show stronger responses than the salt meadows in a distal position. This seems to be due to the retention of water by the obione schorre vegetation, whereas the higher salt meadows are inundated less frequently. In the mineral domain of the foreshore, OPS 5 does not seem to supply any more information than that of the NIR (OPS 3). The channels remain fairly clearly visible.

OPS 6 (2010-2120 nm): This band of the SWIR is strongly correlated with OPS 8 , which is in the same spectral range. On the foreshore, the structure of the estuary channels becomes difficult to decipher. However, distinctions appear which may be attributed to variations 
Table 3. Variance/Covariance/Correlation Matrix: Turbid Plume

\begin{tabular}{llllllll} 
& OPS 1 & OPS 2 & OPS 3 & OPS 5 & OPS 6 & OPS 7 & OPS 5 \\
\hline ()PS 1 & 1.8 & 0.8 & 0.2 & 0.4 & 0.2 & 0.2 & 0.3 \\
()PS 2 & $\mathbf{0 . 3 3}$ & 3.3 & 0 & 0.2 & 0 & 0 & 0 \\
OPS 3 & $\mathbf{0 . 0 6}$ & $\mathbf{0}$ & 6.4 & 3.7 & 1.6 & 0.3 & 3.9 \\
()PS 5 & $\mathbf{0 . 1 0}$ & $\mathbf{0 . 0 4}$ & $\mathbf{0 . 4 9}$ & 9.0 & 1.7 & 0.4 & 3.2 \\
()PS 6 & $\mathbf{0 . 0 9}$ & $\mathbf{0}$ & $\mathbf{0 . 3 8}$ & $\mathbf{0 . 3 4}$ & 2.8 & 0.2 & 1.9 \\
()PS 7 & $\mathbf{0 . 1 3}$ & $\mathbf{0}$ & $\mathbf{0 . 1 0}$ & $\mathbf{0 . 1 2}$ & $\mathbf{0 . 1 0}$ & 1.3 & 0.4 \\
()PS S & $\mathbf{0 . 1 0}$ & $\mathbf{0}$ & $\mathbf{0 . 7 0}$ & $\mathbf{0 . 4 9}$ & $\mathbf{0 . 5 2}$ & $\mathbf{0 . 1 6}$ & 4.5 \\
\end{tabular}

in the nature and/or geometry of the sedimentary bodies. The sensitivity of this band to suspended matter, easy to perceive in the turbid plume, gives "mineral"-type channel responses, as the water here always has a strong response due to the sediment content.

OPS 7 (2130-2250 $\mathrm{nm})$ : This band has a considerable amount of noise, which makes evaluation somewhat difficult. As theoretically predicted, OPS 7 is sensitive to responses from the plant environment. In the SWIR, the physical phenomena observed are mainly reflection and absorption; there is no more transmission. The plant response depends mainly on the total water content, with the thickness of the sheet playing an important role. It can be noted that here, the salt meadows have a much greater reflection than the plants of the schorre and foliage. This behavior can be explained by the structure of the herbaceous plants of the higher zone, the halophytes of the schorre having a very thick, tough epidermis, foliage plants having a thick epidermis compared with the grasses. This makes it possible to obtain a characteristic peak of the vegetation at $2200 \mathrm{~nm}$ which is better expressed in the salt meadows.

Despite the poor quality of this band, the tide level shows up in a comparable manner to the view given by the visible band (OPS 1).

OPS $8(2270-2400 \mathrm{~nm})$ : This band provides information comparable to that of OPS 6 . In digital numbers, OPS 8 is, on average, slightly superior to OPS 6 . It seems that a specific carbonate response can be identified, or at least zones enclosing a high proportion of carbonates. In this case, OPS 6 may be equal or even superior to OPS 8. This appears to be true for certain tangue sectors, for shelly banks such as the one behind the Her-

Table 4. Variance/Covariance/Correlation Matrix: Foreshore Silt and Sand

\begin{tabular}{cccccccc}
\hline & OPS 1 & OPS 2 & OPS 3 & OPS 5 & OPS 6 & OPS 7 & OPS 8 \\
\hline OPS 1 & 6.6 & 3.3 & 4.2 & 4.2 & 3.4 & 5.8 & 3.9 \\
OPS 2 & $\mathbf{0 . 5 7}$ & 5.1 & 2.0 & 1.9 & 1.8 & 2.8 & 2.0 \\
OPS 3 & $\mathbf{0 . 4 6}$ & $\mathbf{0 . 2 5}$ & 12.6 & 11.8 & 7.7 & 4.7 & 7.6 \\
OPS 5 & $\mathbf{0 . 4 2}$ & $\mathbf{0 . 2 2}$ & $\mathbf{0 . 8 5}$ & 15.2 & 8.1 & 5.1 & 7.7 \\
OPS 6 & $\mathbf{0 . 4 7}$ & $\mathbf{0 . 2 9}$ & $\mathbf{0 . 7 8}$ & $\mathbf{0 . 7 4}$ & 7.8 & 3.1 & 6.9 \\
OPS 7 & $\mathbf{0 . 6 7}$ & $\mathbf{0 . 3 7}$ & $\mathbf{0 . 3 9}$ & $\mathbf{0 . 3 8}$ & $\mathbf{0 . 3 3}$ & 11.5 & 3.3 \\
OPS 8 & $\mathbf{0 . 4 8}$ & $\mathbf{0 . 2 8}$ & $\mathbf{0 . 6 8}$ & $\mathbf{0 . 6 2}$ & $\mathbf{0 . 7 8}$ & $\mathbf{0 . 3 1}$ & 10.0 \\
\hline
\end{tabular}

Table 5. Variance/Covariances/Comelation Matrix: Schorre (Vegetation)

\begin{tabular}{|c|c|c|c|c|c|c|c|}
\hline & OPS 1 & OPS 2 & OPS & OPS 5 & OPS 6 & OPS 7 & OPS s \\
\hline OPS I & 14.3 & 9.2 & -7.6 & -8.2 & (i.9) & IS.6 & 5.8 \\
\hline ()PS 2 & 0.79 & 9.4 & -5.9 & -6.5 & 4.7 & 12.1 & (i.) 1 \\
\hline ( OPS :3 & -0.43 & -0.41 & 21.7 & 19.7 & -4.6 & $--|()|$. & -7.2 \\
\hline OPS & -0.45 & -0.44 & 0.87 & 2.3 .5 & -4.4 & -11.6 & -7.2 \\
\hline ()PS 6 & 0.73 & 0.61 & -0.41 & -0.39 & 6.3 & $5 . \overline{5}$ & 6.0 \\
\hline (OPS 7 & 0.83 & 0.66 & -0.36 & -0.40 & 0.57 & 3.5 .4 & 10.7 \\
\hline ()PS 8 & 0.74 & 0.64 & -0.49 & -0.47 & 0.76 & 0.57 & 9.5 \\
\hline
\end{tabular}

melles, and for the turbid plume in which the suspended matter is carbonate rich. The response in OPS 8 is stronger for the zones that are siliceous, such as at Bec d'Andaine, and silty with a high clay content, such as on the lower foreshore.

\section{Complementarity of the OPS Spectral Bands}

Variance/covariance/correlation matrices are given in Tables 2-6. They correspond respectively to the JERS-OPS scene with no selection of specific targets (Table 2), the turbid plume (Table 3), the silty and sand foreshore (Table 4), the schorre (Table 5), and the channels of the lower estuary (Table 6). (See also Figs. 4 and 5.)

Table 2 shows a strong correlation between the two channels of the visible band (OPS 1 and OPS 2, $r=0.9: 3$ ) and the three infrared channels characteristic of the vegetation (OPS 3, OPS 5, and OPS $7 ; r=0.74-(0.88)$. The specific nature of OPS 6 and OPS 8 can be noted; they correlate weakly with the other channels, but strongly with each other $(r=0.87)$. The variances of OPS 3 and OPS 5 are strong $(>95())$ whereas that of OPS 8 is 2.5 times stronger than that of OPS 6 .

In the turbid plume (Table 3), only OPS 6/OPS 8 and OPS $3 /$ OPS 8 show a correlation superior to 0.5. All the channels, and particularly that of OPS 2 , give a weak correlation. For the foreshore (Table 4), results show a good overall correlation associated with the moisture (OPS 5) and the mineral character of the environment (OPS 6 , OPS 8). OPS 3/OPS 5 gives the strongest correlation with 0.85. OPS 5, which shows the strongest variance, reflects the role of the moisture in this spectral band.

In the schorre (Table 5), the strongest correlation is associated with the vegetation, and corresponds to OPS

Table 6. Variance/Covariance/Correlation Matrix: Channels (Turbid Water and Silt)

\begin{tabular}{cccccccc}
\hline & OPS 1 & OPS 2 & OPS 3 & OPS 5 & OPS 6 & OPS 7 & OPS 8 \\
\hline OPS 1 & 24.9 & 12.8 & 18.7 & 17.8 & 0.1 & $2(1.6$ & 7.5 \\
OPS 2 & $\mathbf{0 . 8 4}$ & 9.2 & 9.4 & 8.7 & 0.3 & 11.1 & $4 .(1)$ \\
OPS 3 & $\mathbf{0 . 7 5}$ & $\mathbf{0 . 6 2}$ & 24.7 & $2(1) 1$ & $1 .()$ & $2(1) .5$ & 10.2 \\
OPS 5 & $\mathbf{0 . 6 4}$ & $\mathbf{0 . 5 1}$ & $\mathbf{0 . 7 2}$ & 31.5 & $-(1.5$ & 21.2 & 7.4 \\
OPS 6 & $\mathbf{0 . 0 1}$ & $\mathbf{0 . 0 5}$ & $\mathbf{0 . 1 0}$ & $-\mathbf{0 . 0 4}$ & 4.0 & -1.7 & 2.6 \\
OPS 7 & $\mathbf{0 . 6 6}$ & $\mathbf{0 . 5 8}$ & $\mathbf{0 . 6 6}$ & $\mathbf{0 . 6 0}$ & $-\mathbf{0 . 1 4}$ & 39.2 & 70 \\
OPS 8 & $\mathbf{0 . 5 3}$ & $\mathbf{0 . 4 7}$ & $\mathbf{0 . 7 3}$ & $\mathbf{0 . 4 7}$ & $\mathbf{0 . 4 6}$ & $\mathbf{0 . 4 0}$ & 7.9 \\
\hline
\end{tabular}




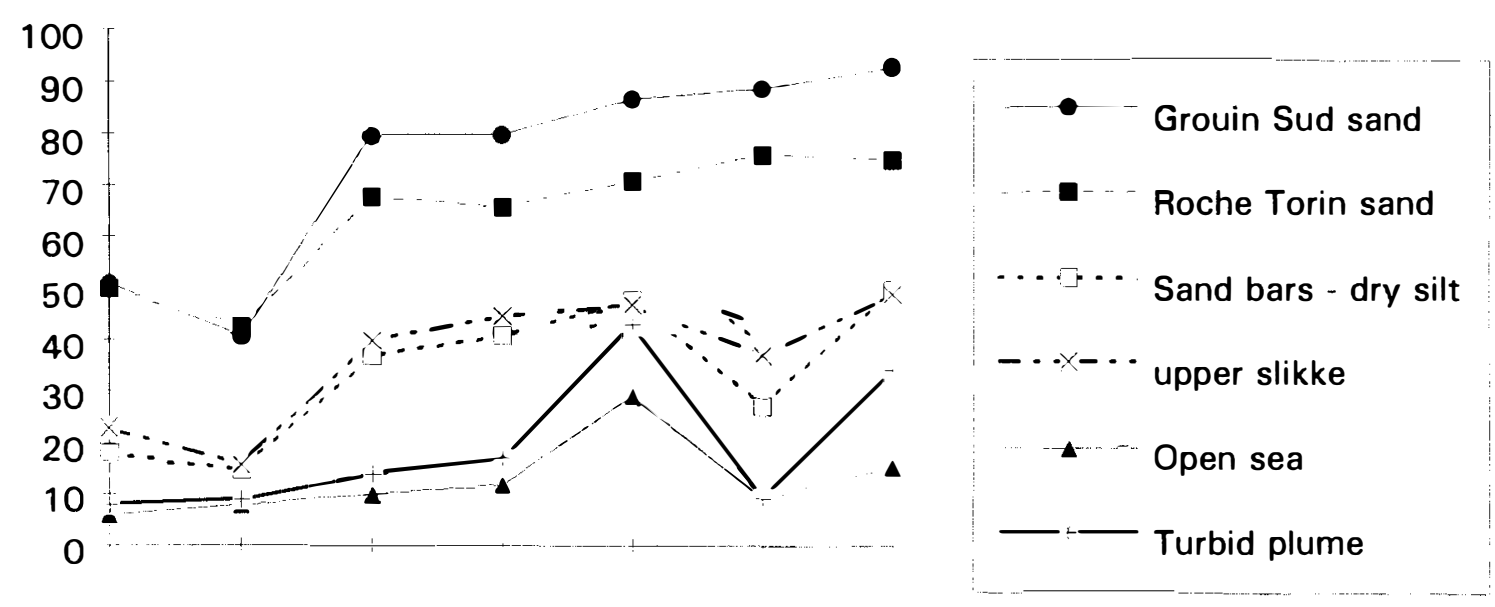

OPS1 OPS2 OPS3 OPS5 OPS6 OPS7 OPS8

Figure 4. OPS mineral responses.

3/OPS 5 with 0.87 ; it can be noted that the value obtained is much the same as in the foreshore domain. Correlations between channels are generally fairly strong, between 0.4 and 0.8 . The lower estuary zone (Table 6) gives good correlation between the channels of the optical range (OPS 1 to OPS 3) and OPS 3/OPS 8, as in the turbid plume. By contrast, the OPS 6/OPS 8 correlation is not so good here.

For the sector that was studied, the separation of the green (OPS 1) and red spectra (OPS 2) is of little interest as they are always strongly correlated and are not discriminating in the mineral zones (weak variances). The respective contributions of the NIR and SWIR is confirmed, especially where vegetation is concerned (Deroin and Deroin, 1996); the schorre plants have a specific behavior compared with the plants growing on land, in particular a strong response in OPS 7 . The contribution of
OPS 6 and OPS 8 seems important in the mineral sectors, or sectors with mineral components (turbid plume of the channels). In the foreshore zone, the strong OPS 6 responses can be related to the high proportions of carbonates, either directly associated with the silts (tangues) and sands (thanatocoenose sand bars) or suspended in the water (approximately 50\% of the particle components). Such characteristics favor the use of. for example, OPS $1: 36$ type composition (Figure 6).

\section{The Ratio Approach}

Vegetation index: The use of the NIR/VIS ratio, also known as the "vegetation index," can contribute to a better discrimination of responses either within vegetation units or between vegetation units and predominantly mineral units (e.g., Deroin et al., 1990).

The values obtained (Table 7 ) can be divided into

Figure 5. OPS vegetation responses.

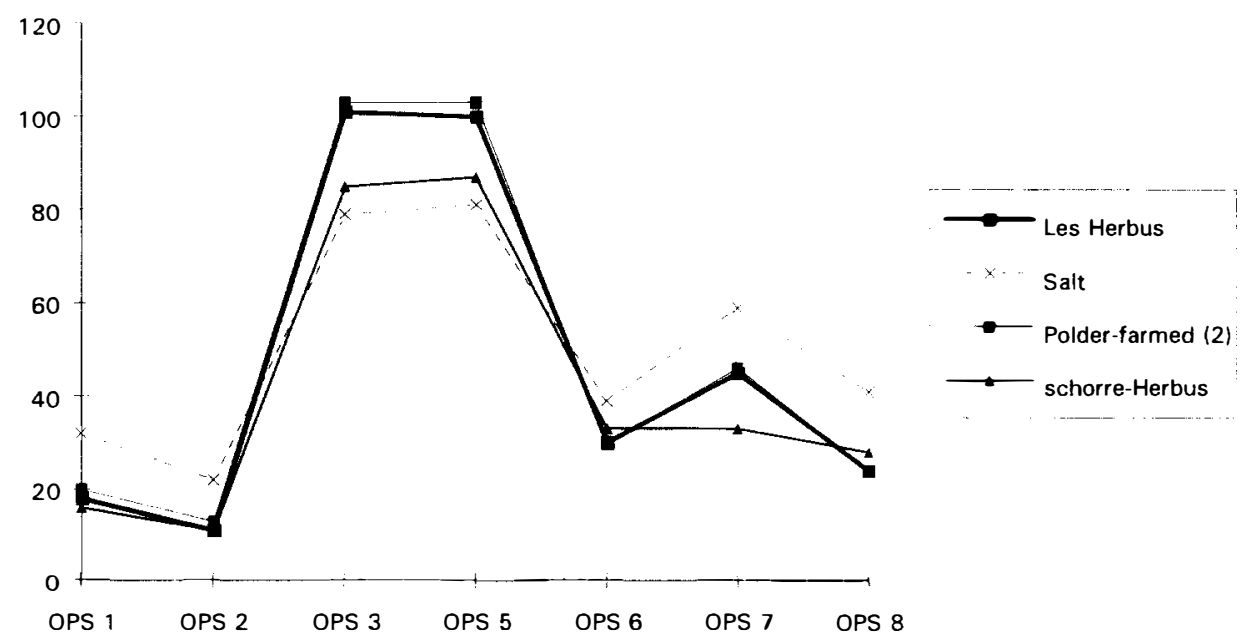




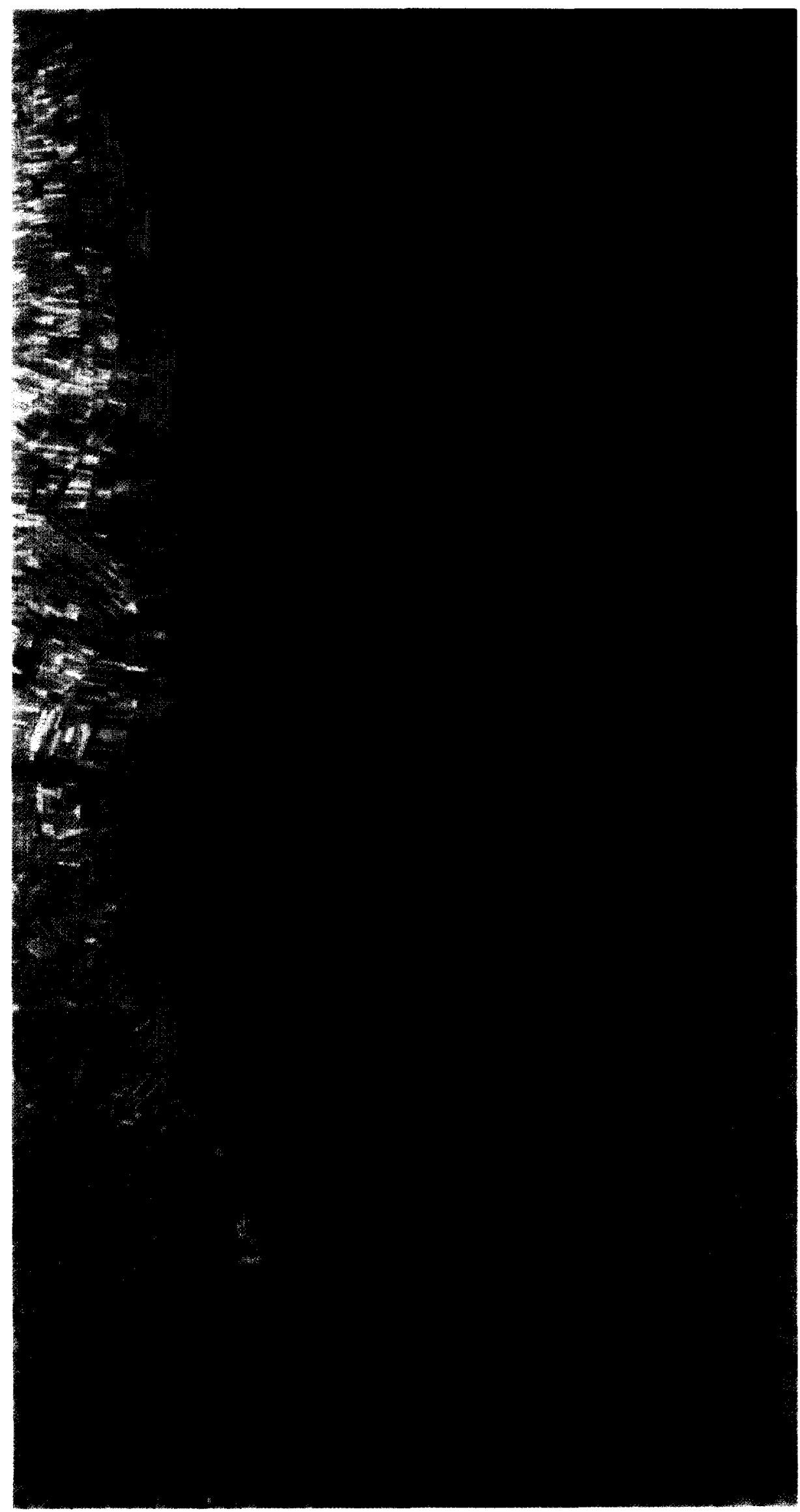

Figure 6. JERS-OPS color composite: red (OPS 1), green (OPS 3 ), blue (OPS 6). Western part of the bay (surface: about $3.50 \mathrm{~km}^{2}$ ). 
Table 7. Raw Digital Numbers

\begin{tabular}{|c|c|c|c|c|c|c|c|c|c|}
\hline \multirow[b]{2}{*}{ OPS } & \multirow{2}{*}{$\frac{\text { Green }}{1}$} & \multirow{2}{*}{$\frac{\text { Red }}{2}$} & \multirow{2}{*}{$\frac{N I R}{3}$} & \multirow{2}{*}{$\frac{\text { SWIR }}{5}$} & \multirow{2}{*}{$\frac{S W I R}{6}$} & \multirow{2}{*}{$\frac{S W I R}{7}$} & \multirow{2}{*}{$\frac{S W I R}{\delta}$} & \multicolumn{2}{|c|}{ RATIOS } \\
\hline & & & & & & & & $.5 / 8$ & $3 / 1$ \\
\hline \multicolumn{10}{|l|}{ Mineral environment } \\
\hline Andaine' sand & 49 & 45 & 78 & 77 & 79 & 87 & 90 & 0.86 & 1.59 \\
\hline Grouin Sud sand & 51 & 41 & 80 & 80 & 87 & 89 & $9: 3$ & 0.86 & 1.57 \\
\hline Roche Torin sand & 50 & $4: 3$ & 68 & 66 & ו & 76 & 75 & $0 . s s$ & 1.36 \\
\hline La Larrouière bank & $3: 3$ & 32 & 57 & 72 & $6 \overline{5}$ & 44 & 72 & 1.00 & 1.73 \\
\hline Les Hermelles & 39 & 28 & 66 & 61 & 66 & 56 & $7 s$ & $0.7 s$ & 1.69 \\
\hline SE Hermelles & 16 & 13 & 38 & 42 & 48 & 26 & 46 & 0.91 & 2.38 \\
\hline Watter line: & 47 & 39 & 59 & 61 & 66 & 7() & 68 & 0.90 & 1.26 \\
\hline Upper slikke & 23 & 16 & 40 & 45 & 47 & 37 & 49 & 0.92 & 1.74 \\
\hline Sand bars-dry silt & 18 & 15 & 37 & 41 & 48 & 27 & 50 & 0.52 & 2.06 \\
\hline Lower loreshore & 9 & 12 & 41 & 42 & 50 & 14 & $\left.\tilde{j}^{\prime}\right)$ & 0.84 & 4.56 \\
\hline (Open sea & 6 & 8 & 10 & 12 & 29 & 9 & 1.5 & (0.80) & 1.67 \\
\hline Turbid plume & 8 & 9 & 14 & 17 & $4: 3$ & 9 & 34 & 0.50 & 1.75 \\
\hline Polder-ground (1) & 42 & 39 & 69 & $3: 3$ & 44 & $8: 3$ & 57 & 0.58 & 1.64 \\
\hline Polder-ground (2) & $3: 3$ & 21 & 64 & 67 & 44 & 57 & 44 & 1.52 & 1.94 \\
\hline Polder-ground (3) & 44 & 3.5 & 57 & $5: 3$ & 39 & 69 & 44 & 120 & 1.30 \\
\hline \multicolumn{10}{|l|}{ Vegetation enviromment } \\
\hline Schorre-east & 16 & 10 & 78 & 82 & $3: 3$ & 32 & 26 & 31.5 & 4.88 \\
\hline Schorre-west & 14 & 12 & 9] & 95 & $3: 3$ & 33 & 26 & 3.6 .5 & 6.50 \\
\hline Schorre-grassy & 16 & 11 & 85 & 87 & $: 3: 3$ & $3: 3$ & 28 & 3.11 & 5.31 \\
\hline Salt meadows & 32 & 22 & 79 & 81 & 39 & 59 & 41 & 1.95 & 2.47 \\
\hline Salt meadows SE & 30) & 22 & $8: 3$ & 82 & $: 35$ & $6: 3$ & 34 & 2.41 & 2.77 \\
\hline Les Herbus forest & 18 & 11 & $|0|$ & 100 & 30 & 4.5 & 24 & 4.17 & 5.61 \\
\hline St.-Léonard Forest & 22 & 1.5 & 92 & 97 & 34 & 49 & 27 & 3.59 & 4.18 \\
\hline Tombelaine (island) & 20 & 19 & 72 & 78 & $: 3: 3$ & 34 & 26 & 3.00 & 3.60 \\
\hline Polder-larmed 1 ! & 20 & 14 & 95 & 94 & 3.5 & 37 & 31 & $3.0: 3$ & 4.75 \\
\hline Polder-larmed 2! & 20 & $1: 3$ & 103 & $10: 3$ & 30 & 46 & 24 & 4.29 & 5.15 \\
\hline Polder-pasture & 19 & 2) & 96 & 94 & $3: 3$ & $: 35$ & 29 & 3.24 & 5.05 \\
\hline
\end{tabular}

two categories: plant responses or those influenced by vegetation (OPS 3/OPS $1>2.40$ ) and mineral responses or those with little differentiation (OPS 3/OPS $1<2.40$ ). The bare ground of the polders can have a variable index (OPS :3/OPS 1 from 1.30 to 1.94 ) especially in relation to their mineral composition (variability of OPS 1 ). The salt meadows, as indicated above, have responses in OPS 3 that are below the average for the vegetation, which, associated with high values in OPS 1 (twice those of the

Table \&. Semisupervised Classification of the JERS-OPS Image

\begin{tabular}{|c|c|c|c|}
\hline & Pixels & $h a$ & $\%$ \\
\hline Seal water (masked) & () & () & () \\
\hline Turbicl plume & 7506 & $24: 3.2$ & 1.5 \\
\hline Chammels (water) & 45,687 & 1480.3 & 9.2 \\
\hline Saturated silt (chammels) & 111,929 & 3626.5 & 22.6 \\
\hline Silty slikke & 103,192 & $3: 34: 4.4$ & 20.9 \\
\hline Sand bank (slikke) & 9216 & 298.6 & 1.9 \\
\hline Sandy spit (Andaine) & $2: 3,3() 1$ & 754.9 & 4.7 \\
\hline Interchammel sand & $1: 38,066$ & $447: 3.3$ & 27.9 \\
\hline Dense schorre & $82: 34$ & 2668 & 1.7 \\
\hline Graded schorre & $11,57: 3$ & 375.0 & 2.3 \\
\hline Schorre (upper slikke) & 21,728 & 7() 4.0 & 4.4 \\
\hline Salt moadows & 14,077 & 456.1 & 2.9 \\
\hline Total & 494,509 & $16,(022.1$ & 100 \\
\hline
\end{tabular}

Silt $4.3 .5 \%$, sand $34.5 \%$, vegetation $11.3 \%$, and lref water $10.7 \%$. schorre), gives an index of 2.47-2.77. This environment is highly influenced by the mineral component (eolian veil) and the climate.

OPS 5/OPS 8 mineral index: This perfectly discriminates the mineral domain (OPS $5 /$ OPS $8<1$ ) from the plant domain (OPS 5/OPS 8>3). For the latter domain, the salt meadows are again intermediate with OPS $5 /$ OPS $8 \cong 2$. Polders at 1.5 and 1.2 represent an intermediate domain with both mineral and plant component.

The mineral domain remains little differentiated. The sands are homogeneous and give a OPS 5/OPS 8 ratio of $<0.90$, which would result from the specular component of the reflection (OPS $8>$ OPS 6). For the sand bars and the lower foreshore, the values of 0.80 0.90 can be explained by the high carbonate contents, OPS 6 being in this case close to OPS 8. For the silty zones. an effect, which is certainly momentary, is produced by the strong clay response in OPS 5 .

\section{Spatial Approach by Semisupervised Classification}

A semisupervised classification of the JERS scene was carried out. The ground control survey was not done at the same time as the acquisition, but it did reveal invariant zones which were used as practice plots. The sea section of the image was masked out in order to only take into account the spectral characteristics of the foreshore 
itself. One of the objective's was also to quantify the sur-face of the different mits over the exposed $160 \mathrm{~km}^{-}$ (or

$16,(22.2$ ha) as a whole, that is, some $5(0),(0)(0)$ pixels. Thus it is seen that over $30 \%$ of the $250 \mathrm{~km}^{2}$ of the hai is (xposed (Table 8).

The classification provides a reference status for comparison with the results of other classifications on data ac-quired at diffe rent dates, and possibly with other sensors.

\section{DISCUSSION/CONCLUSIONS}

The spectral bands of JERS-OPS cover the visible, NIR and SWIR ranges. In the visible range, the OPS 1 and OPS 2 responses are strongly correlated and contribute little detailed information. The main originality of the OPS sensor is that it has three bands around the 220() $\mathrm{nm}$ peak. Considered in detail, one of these bands covers the reflection peak of (arbonates (OPS 6), which are characterized on JERS-OPS by high values (close to these acquired in OPS 8) and a strong variance. The response in OPS 5 is closely related to the moisture which, in essentially mineral zones such as the foreshore. enables observation of strong variance.

A detailed study of bands OPS 3, OPS 5, and OPS 7 , characteristics of the vegetation, made it possible to highlight the behaviors of specific vegetation units of the foreshore (schorre, salt meadows), which can be distinguished from land plants by their structure and potential for retaining water.

JERS-OPS is a satellite sensor which combines the advantage of standard high spatial resolution $(18 \mathrm{~m})$ and a good discriminating capacity in the standard spectrum of terrestrial ohjects between $400 \mathrm{~mm}$ and $2500 \mathrm{~nm}$. The bands centered on mineral characteristics, which makes this the only satellite dedicated to geological prospecting, ensure the recognition of sediment types, which is not possible with Landsat-TM or Spot-XS.

We wish to thank the National Space Development Agency of Japan (NASDA) for supplying the JERS-OPS data studied within the scope of the System Verification Program (Pilot Proj-ect J.03(0.5), and also J--R. Disnar (CNRS, Orléans), who ana-lyzed the organic matter. Ph. L. Hauff (Spectral Intermational, Inc., USA) provided us with information on high spectral reso-lution. BRGM funded this research work within the scope of the "Littoral" project (P ()3). The Conseil Régional of the Basse-Nomnandie cofunded a srant toucards a doctorate awared by Caen University.

\section{REFERENCES}

Baban, S. M. J. (1993), The evaluation of different algorithms for bathymetric charting of lakes using Landsat imagery. Int.

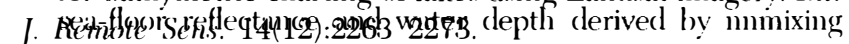
Bierwirth, P. N., Lee, T. J., and Burne, R. V. (19993), Shallow

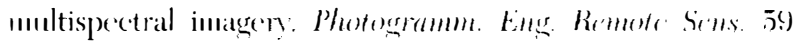
(3):331 33:35.

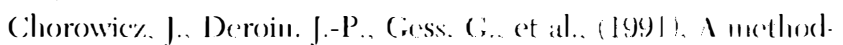
ology for the use of Spot intagery in oil exploration. Fiximple of the Bas Languedoc exploration permits area France?. Int. J. Re'mote Sens. 12(10):2(1)8;-2108.

Deroin, J.-P., and I)eroin, Th. (1996). The relationships anong vegetation, geology, and spectral response: a (puantitative ap)proach on the European Beced (Fassus syluatica, Fagaceade). Fragmenta Floristica Geobol. Krakóne 41(2):791-\$0)

Deroin, J.-P.. (Chorowic\%, I., Deroin, T., Dntartre. P., Scantic, J.-Y., and Simonin. A. (1990)), The landscape(-1mit approach applied to gcology, on SPOT images, in temperate climate zones using a test-area in the Cévemnes (Massif central. France). ISPRS J. Photogramm. Remote Sens. 45:35:-40:3.

Deroin, J.-P., Lebret, P., Marchand, Y., and Trantmann, Fr. (1994). Faaluation of the JERS-I OPtical Sensor data on Western France. Geological aspects (Project J-(0)30.5). In Final Report of JERS-I/ERS-I System Verification Prouram, NASIDA-ERSDAC, Tokvo, Vol. 1, pp. 581-.586.

de Sourat Fillo, C. R., Drury, S. A., and Carlton, R. W. T. (1994). Noise removal and inlage restoration of Fuvo-I (JERS-1) inagery. Approaches in the spatial and frequency domains. In Final Report of JERS-I/ERS-I System Verification Program, NASDA-ERSDAC, Tokyo, Vol. 1, pp. 179-190. Garlan, Tlı. (1991), L'apport des domées satellitaires pour la cartographie du domaine littoral. In Actes du Congrés Ocean Space Advanced Techologies European Space, 24-27 September, Brest, Session B, 11 pl).

Ginyot, (B. (19S9)), Signatures Spectrales des Surfaces Naturelles, Ed. Paradigme, Caen, ITs pl).

Hunt, (. R., and Salisburv, J. WI. (1970), Visible and ncar-infratred spectra of minerals and rocks: I. Silicate minerals. Modern Geolosy 1:28:3-300.

Hunt, G. K., and Salisbury, J. W. (1971), Visible and near-infrared spectra of minerals and rocks: II. Carbonates. Modern Geology 2:233--30.

Katoh, M. (1994), Classification of conifer tree species using JERS-I (OPS. In Final Report of JERS-1/ERS-1 System Verification program. NASDA-ERSDAC, Tokyo, Vol. 2, pp. S1-S5.

Kanfmam, H., Berger, M., and Wetzel, H.-U. (19)4), Effectiveness of FUYO-1 (JERS)/()PS-SWIRR bands for mincral exploration. In Final Report of JERS-1/ERS-I System Verification Program, NASIDA-ERSDAC: Tokvo, Vol. I, P). $45 \overline{5}-\overline{5}() 1$.

Kruse, F. A., Kierein-Yomg, K. S., and Boardman, J. W. (1990), Mineral mapping at Cuprite, Nevada witls a 6i3chamnel imaging spectrometer. Photogramm. Eng. Remote Sens. 56(1):83-92.

Lang, 11. R., Bartholomew, M. J., Grove, (: 1., and Paylor, F. D. (1990), Spectral reflectance characterization (0.4 to 2.5 and 8.0 to $12.0 \mu \mathrm{m}$ ) of Phamerozoic strata, Wind River Basin and Sonthern Bighorn Basin areas, Wyoming. J. Sedimentary Petrol. 6(0)(4):5()5-524.

Lang, J., Lucas, (.., and Mathieu, R. (1973), Le domaine benthique de la baie du Mont-Saint-Michel (Manche). Sciences de la Terre $18(1): 21-78$.

Larsommeur, (. (1989), La Baie dn Mont-Saint-Michel: 111 modèle de sédinentation en zone tempérée. Bull. Inst. Cóonl. Bassin dityitaine 46:5-64. 
L'homer, A., and Minoux, L. (1987), Applications des données multispectrales Spot à la cartographie des sédiments de la baie du Mont-Saint-Michel (Bretagne et Nornandie, France). In Proceedings of "Mer et Littoral, Couple à Risque," Biarritz, France, 13 pp.

Malila, W. A., and Meyers, T. J. (1994), Initial tasseled-cap transform for JERS-1 multispectral data. In Final Report of JERS-1/ERS-1 System Verification Program, NASDAERSDAC, Tokyo. Vol. 1, pp. 171-178.

Marchand, Y. (1996), Cartographies sédimentologiques et morphologiques par télédétection de la baie du Mont-SaintMichel - Comparaison de méthodes de segmentation d'images multi-capteurs, Doctoral thesis, Université de Caen, Document BRGM, 96 pp.

Nishidai. T. (1993), Early results from "Fuyo-1" Japan's Earth Resources Satellite (JERS-1). Int. J. Remote Sens. 14(9): 18251833.

Okada, K., Suzuki, M., and Nishidai, T. (1994), JERS-1 verification program: Silver Bell Area, Arizona, USA. In Final Report of JERS-1/ERS-I System Verification Program, NASDAERSDAC, Tokyo, Vol. 1, pp. 604-61.5.

Pestre, C., and Verger, F. (1980), Gémorphologie de la baie du Mont-Saint-Michel par télédétection des lignes de rivage instantanées. In Actes 3rd Int. Colloq. GDTA “Cartographic Processing and Analysis of Satellite Imagery. Annales des Mines, Toulouse, pp. 175-181.

Pirazzoli, P. A. (1984), Cartographie des hauts fonds par télédétection dans l'archipel des Gambier (Polynésie française). Rev. Espace Géogr. 3:277-284.

Porter, W. M., and Enmark, H. T. (1987), A svstem overview of the airborne visible/infrared spectrometer (AVIRIS). In Proceedings 31st Annual International Technical Symposium (SPIE), Ann Arbor, MI.

Spitzer. D. (1989), Bottom influence on the reflectance of the sea. Int. J. Remote Sens. 8(3):279-290.

Taranik, J. V., Elvidge, C. A., and Grimes, J. P. (1994), Evaluation of JERS-1 synthetic aperture radar and optical sensor image data for analysis of geologic structures and mineralized areas, West-Central Nevada, USA. In Final Report of JERS-1/ERS-1 System Verification Program, NASDAERSDAC, Tokyo, Vol. 1, pp. 209-216.

Whitney, C., Abrahms, M. J., and Goetz, A. F. (1983), Mineral discrimination using a portable ratio-determining radiometer. Econ. Geol. 78:688--698. 